\title{
Correction to: An economic analysis of the proposed Dhaka-Chittagong Expressway in Bangladesh with the viewpoint of GHG emission reduction
}

\author{
Md. Zia Uddin ${ }^{1} \cdot$ Takeshi Mizunoya $^{2}$ (1)
}

Published online: 29 October 2019

(c) The Author(s) 2019

\section{Correction to: Asia-Pacifc Journal of Regional Science https://doi.org/10.1007/s41685-019-00136-5}

The article An economic analysis of the proposed Dhaka-Chittagong Expressway in Bangladesh with the viewpoint of GHG emission reduction, written by Md. Zia Uddin and Takeshi Mizunoya, was originally published electronically on the publisher's internet portal on 26 September 2019 without open access. With the author(s)' decision to opt for Open Choice the copyright of the article changed on 23 October 2019 to (C) The Author(s) 2019 and the article is forthwith distributed under a Creative Commons Attribution 4.0 International License (https://creativeco mmons.org/licenses/by/4.0/), which permits use, sharing, adaptation, distribution and reproduction in any medium or format, as long as you give appropriate credit to the original author(s) and the source, provide a link to the Creative Commons license, and indicate if changes were made.

The original article has been updated.

Open Access This article is distributed under the terms of the Creative Commons Attribution 4.0 International License (http://creativecommons.org/licenses/by/4.0/), which permits unrestricted use, distribution, and reproduction in any medium, provided you give appropriate credit to the original author(s) and the source, provide a link to the Creative Commons license, and indicate if changes were made.

The original article can be found online at https://doi.org/10.1007/s41685-019-00136-5.

Takeshi Mizunoya

mizunoya.takeshi.ff@u.tsukuba.ac.jp

Md. Zia Uddin

zuddin01@gmail.com

1 Graduate School of Life and Environmental Sciences, University of Tsukuba, Tsukuba, Japan

2 Faculty of Life and Environmental Sciences, University of Tsukuba, Tsukuba, Japan 